\title{
Patenting protein sequences
}

\author{
Cheryl H. Agris
}

When drafting a patent application, it is important to recognize the subtle differences that may be inherent in the type of subject matter claimed. For example, distinct sets of issues pertain when drafting claims for DNA sequences $^{1}$ versus proteins. This has strategic importance because the claims section of the patent-located at the end of the patent specification-legally defines the invention protected by the patent $t^{2}$.

\section{A blueprint for protein patenting}

Advances in recombinant DNA and DNA sequencing techniques have led to the isolation and characterization of DNA sequences and the discovery and isolation of novel proteins. Proteins may perform a variety of functions: acting as enzymes, controlling gene function, recognizing and binding other proteins and biomolecules, controlling membrane permeability, and regulating metabolite concentration $^{3}$. Therefore, they have important implications for the development of therapeutic and industrial agents.

Once it has been determined that a protein is patentable, the second determination is what should be included in the claims. It is not enough to claim the protein itself. The patentability of proteins is discussed in a number of publications $s^{4}$. This article will discuss which claims are necessary and appropriate for protein sequences.

\section{What to claim}

A claim should be drafted to the protein itself, for example: "An isolated polypeptide sequence depicted in SEQ ID No. 1.” Additionally, a claim may be drafted to cover homologs that have a certain percent identity to the protein sequence. In such cases, it is important to include a description of the method or algorithm used to determine the sequence's identity in the application.

To provide greater breadth, a "fingerprint" claim may be drafted in which various identifying characteristics are recited, for example: "An isolated glucose oxidase having a $\mathrm{pH}$ optimum in the range of $\mathrm{pH} 6-7$, determined at $30^{\circ} \mathrm{C}$ with $\mathrm{D}$-glucose as substrate, and having more than $75 \%$ of maximum activity at $\mathrm{pH} 8$, determined at $30^{\circ} \mathrm{C}$ with D-glucose as substrate, and obtained from a strain of Cladosporium oxysporum, designated as CBS 163.94." ${ }^{\prime 5}$ Another

Cheryl H. Agris is a patent attorney based in Pelham, NY, and is special counsel to Baker and Botts, LLP (c.agris.patlaw@pobox.com). example of a fingerprint claim is a partial amino acid sequence recited along with other identifying characteristics: "A substantially pure circulatory polypeptide isolated from blood serum of a rat, which polypeptide has an increased bone apposition rate and has the following N-terminal amino acid sequence (SEQ ID No. 1): Gly-Pro-Gly-Gly-Ala-Gly-Thr-LysPro-Ile". If a nucleic acid sequence encoding the polypeptide has been isolated, claims should be drafted to this sequence, for example: "A nucleic acid sequence which encodes a

\begin{tabular}{ll}
\multicolumn{2}{l}{$\begin{array}{l}\text { Table 1. Possible uses for proteins and } \\
\text { use claims that should be drafted. }\end{array}$} \\
\hline Method of use & Claims to be drafted \\
\hline $\begin{array}{ll}\text { Assay for a } \\
\text { compound }\end{array}$ & $\begin{array}{l}\text { Assay method } \\
\text { Kit } \\
\text { Vaccine }\end{array}$ \\
$\begin{array}{l}\text { Vaccine formulation } \\
\text { Mechanism of action } \\
\text { Method of preparation }\end{array}$ \\
Industrial & $\begin{array}{l}\text { Formulation } \\
\text { Method of use }\end{array}$ \\
& $\begin{array}{l}\text { Formulation } \\
\text { Method of use }\end{array}$
\end{tabular}

polypeptide depicted in SEQ ID No. 1.”

It is also very important to include claims to a method for isolating the polypeptide in order to take advantage of the US Process Patent Amendments Act of $1988^{7}$ and of 35 U.S.C. 271(g). The Process Patent Amendments Act empowers the International Trade Commission to issue an exclusion order of a product made, produced, or processed abroad if the product was made by a process covered by a valid and enforceable patent. 35 U.S.C. $271(\mathrm{~g})$ states that "whoever without authority imports into the United States or uses or sells within the United States a product which is made by a process patented in the United States shall be liable as an infringer." Without such claims, a foreign manufacturer could use a process for making a protein to produce the protein and then import it into the US. An example of such a claim is: "A method of obtaining a polypeptide from a mammal which stimulates bone growth in a mammal comprising the steps of: (a) feeding the mammal a calcium deficient diet to increase the level of the polypeptide in the blood of the mammal; (b) isolating a sample of the blood serum of the mammal; and (c) collecting from the sample in substantially pure form a polypeptide having the N-terminal amino acid (SEQ ID No. 1) Gly-Pro-Gly-GlyAla-Gly-Glu-Thr-Lys-Pro-Ile."

One should also consider the possible uses of a given protein. Possible uses and claims to be drafted are shown in Table 1. Proteins may be used in screening assays for a particular compound $^{8}$. In such instances, they may act as receptors. A protein may also be used in a vaccine formulation if it has antigenic properties ${ }^{9}$. Proteins in a vaccine formulation usually require a carrier or adjuvant. Claims may also be directed to a method for inducing an immune response.

If the protein is being used for therapeutic purposes, claims should be directed to a formulation that contains the protein that may be useful. For example, if it has been found that a particular protein may act alone or with another protein, claims should be drafted to "A formulation comprising protein $\mathrm{X}$ and a carrier" as well as to "A formulation comprising protein X and protein Y." Claims should also be directed to the specific mechanism of action of the protein as well as to a method for treating a given disorder, for example: "A method of inhibiting the binding of virus $A$ to a cell of a patient comprising applying peptide A to said cell in an amount sufficient to inhibit the binding of said virus to said cell." The success of claims directed to therapeutic uses will depend on supporting evidence presented in the application or in a declaration during prosecution of the application. Generally, such claims may be obtained by showing in vitro data and/or results of animal studies.

If the protein is being used for industrial purposes, there should also be claims to all possible formulations. For example, if the protein is being used as a detergent, claims should be drafted to a detergent formulation and detergent additive.

\section{Conclusion}

It is important to draft claims that cover not only the sequence itself but related sequences that identify characteristics of the protein, such as the nucleotide sequences encoding the protein, methods for obtaining the protein, possible formulations containing the protein, and any potential uses of the protein.

\footnotetext{
1. Agris, C.H. 1998. Nat. Biotechnol. 16:877.

2. 35 U.S.C. 112.

3. Darnell, J. et al. 1990. Molecular cell biology. 2nd ed. W.H. Freeman and Co., New York.

4. See, for example, Faber, R.C. 1997. Chapter IX in Landis on Mechanics of Claim Drafting. 4th ed. Practicing Law Institute, New York

5. See, for example, US Patent No. 5,741,688.

6. See, for example, US Patent No. 5,786,327.

7. Pub. L. No. 100-418, Title IX, Subtitle A, 101 Stat. 128 (1988), codified as 19 U.S.C. 1337 (1991).

8. See, for example, US Patent No. 5,753,346.

9. See, for example, US Patent No. 5,648,080.
} 